\title{
Existential Alternative for Europe?
}

\author{
The Belt and Road Initiative and Its Impact \\ on Europe
}

Enrico Fardella, Giorgio Prodi

\begin{abstract}
The Belt and Road Initiative (BRI), originally aimed at domestic economic development, has turned into an umbrella bringing together China's ambitious projects to shape a new order in Eurasia, which directly influences Europe. The authors represent both Chinese and European perspectives on this issue.

The BRI has become a mechanism to represent China abroad as well as a tool to ensure China's competitive advantage in the world trade.

This also has an impact on the entire trade system redirecting trade flows and making countries to compete for investments, which alters the existing order and each country's place in this order. Buying shares of Italian strategic national companies, gaining control over ports and terminals along the BRI sea route, for example, the port of Piraeus, and other investments recently made by China force European countries to adapt its economic strategies to new conditions.
\end{abstract}

Key words: Belt and Road Initiative (BRI), China, Europe, trade, investments, railways, transportation

Enrico Fardella is a Tenured Associate Professor and Executive Director at the Centre for Mediterranean Area Studies, History Department, Peking University, China.

enricofardella@gmail.com

Giorgio Prodi is an Associate Professor at the Department of Economics and Management, Ferrara University, Italy. giorgio.prodi@unife.it

This article is an abridged and revised version of the paper written for the Valdai International Discussion Club. The original copy is available at: $h t t p: / / v a l d a i c l u b . c o m / a / v a l d a i-p a p e r s / v a l d a i-$ paper-82-the-belt-and-road-initiative/

DOI: 10.31278/1810-6374-2018-16-2-164-176 


\section{THE ORIGINS OF THE BELT AND ROAD INITIATIVE}

When Chinese President Xi Jinping during his official visit to Kazakhstan in September 2013 launched the Belt and Road Initiative (BRI), his signature foreign policy initiative, he certainly did not have Europe in mind.

The first embryo of the BRI was deeply rooted in Chinese domestic policies. At that time, the newly appointed Secretary General of the Chinese Communist Party was absorbed by its fierce anti-corruption campaign and at the same time in a simultaneous and difficult attempt to rebalance Chinese economic growth. Foreign policy agenda was mostly focused on regional tensions due to the U.S. new "pivot" to Asia and growing disputes with neighboring countries (Japan, the Philippines, and Vietnam in primis). In this context, the BRI had a twofold function:

- expand the scope of the Great Western Development Strategy, the national campaign aimed to boost the development of Chinese internal provinces, by improving infrastructural and economic communications between Chinese poorer provinces and neighboring areas, such as Central Asia;

- devise a successful hedging strategy vis-à-vis the U.S. rebalancing in Asia via a continental policy aimed to expand Chinese influence in areas not controlled by pre-existing hegemonic orders.

Europe was just a peripheral component of the BRI, mostly functional to revive the legendary aura of the Silk Road that peacefully crossed Eurasia.

The implementation of the BRI was attributed to the National Development and Reform Commission, an inward-looking institution devoted to the development of the planned economy and, hence, poorly equipped for the development of international cooperation. In its first year of existence, the BRI was mostly mentioned in subsections of official documents related to Chinese domestic economic development-as in the December 2014 yearly report of the Central Economic Work Conference-and it was never associated with economic relations with Europe. 
In the diplomatic field, the BRI started making its timid appearance at the beginning of 2014 in Xi Jinping's conversations with some key regional partners, including his meeting with Russian President Vladimir Putin during the opening of the Winter Olympic Games in Sochi. Interestingly enough, at the official meetings held on the same days by Xi Jinping with some European leaders, such as Czech President Miloš Zeman and Greek President Karolos Papoulias, the BRI was never mentioned.

A few weeks later, during his official visit to Paris for the celebration of the 50th anniversary of Sino-French diplomatic relations, President $\mathrm{Xi}$ Jinping gave an inspiring speech deeply influenced by his top ideologue Wang Huning's "China's Dream" idea based on the great renewal of the Chinese nation. "Napoleon Bonaparte," he said, "once compared China to a sleeping lion and observed: 'When she wakes she will shake the world.' Now China, the lion, has awakened, but it is a peaceful, amicable, and civilized lion." It is a very powerful and symbolic image indeed: Xi Jinping, the leader of the "awakened lion," for the French is the personification of Napoleon's prophecy and for the Chinese, who traditionally believe in the ability of the lion to protect humans from evil, he acquires a metapolitical legitimation. Yet, that eloquent symbolism notwithstanding, no mention of Xi Jinping's signature project was made by the Chinese leader in France, nor in Germany a few days later.

These trips, however, were part of a wider charm offensive towards Europe in an important moment for the negotiations on the Transatlantic Trade and Investment Partnership (TTIP) between Washington and Brussels. This partnership risked to jeopardize China's advantages in trading with the Old Continent, and this posed a threat to Xi Jinping's attempt to sustain China's economic transition to a more stable economic growth (the so-called "new normal").

\section{XI'S PUSH FOR EUROPEAN MARKETS}

While Xi Jinping was engaged in his trips to European countries, Chinese financial institutions started flooding Europe with investments. Italy, a rich European country significantly affected by the financial crisis, a dynamic manufacturing power in desperate need 
of investments, and, what is most importantly, the rotating president of the Council of the EU since July 2014, was chosen as the entry point of the Chinese investment strategy. In 2014, Italy became the recipient of a sudden flow of calibrated investments by the People's Bank of China that acquired $2 \%$ of some companies that are strategically important for the country, namely ENI, ENEL, Fiat-Chrysler, Telecom Italia, Generali, and Mediobanca. This symbolic threshold automatically led to a public communication by CONSOB, the Italian authority for the regulation of the stock exchange.

This was a strong political message from Beijing that seemed to have a positive impact on the European public perceptions of China. Between the spring of 2014 and the spring of 2015 the Pew Research Center registered a hike in the European public opinion of China with favorable views growing in Italy $(+14 \%)$, Germany $(+6 \%)$, and France (+3\%) (Wike, Poushter, Silver, Bishop, 2017). Yet, the BRI had not been public still.

The first mention of the BRI appeared in Europe in 2015. The severe anti-corruption campaign had reinforced Xi Jinping's position within the party and probably weakened some internal resistance to a sound promotion of his ambitious plan. The Chinese government then started to re-launch the BRI by pushing under its umbrella all the latest and earlier Chinese initiatives for the Old Continent.

The National Development and Reform Commission together with the Ministry of Foreign Affairs and the Ministry of Commerce published China's first official action plan on the BRI, a vague but reassuring document that presented the BRI as China's proposal for a peaceful development of Eurasian connectivity (Vision and Actions, 2015). This seemed to be coupling well with the European Commission's Investment Plan for Europe (IPE), better known as the Juncker Plan, a large investment program aimed to attract investments, which was announced in November 2014.

In March 2015, the UK, Germany, France, and Italy joined the Asian Infrastructure Investment Bank (AIIB), which is the BRI's main multilateral bank guided by Beijing. It was an epoch-making gesture of confidence made by the main European powers, which meant their 
acceptance of China's contribution to global development and its role in the world order.

A massive flood of Chinese BRI-branded investments in Europe followed (+36\% in 2015) (see EU-China FDI Monitor, 2015). Italy again became the recipient of the most important and symbolic investments: ChemChina's $\$ 7$ billion acquisition of the Italian tire maker Pirelli completed with the participation of the Silk Road Fund, a newly-established state-owned investment fund aimed to foster investment in countries along the BRI (see: Silk Road Fund joins ChemChina in industrial investment in Pirelli \& C.SpA, 2015).

In the same months, $\mathrm{Xi}$ Jinping started to boost the image of the BRI abroad by embarking on the most active diplomacy tour in the history of the PRC (Michael, 2016). The apex of this international promotional campaign of the Chinese leader was reached in the so-called "super" state visit to the UK in October 2015. The marvelous reception given to the Chinese President, the first one to visit London in ten years, by the Royal family strongly enhanced Xi Jinping's image in China and abroad (Why is Xi's UK trip called a "super state visit", 2015).

In the following months, the BRI became one of Xi Jinping's main promotional tools within China for his political "campaign" in the run-up to the 19th Party Congress held in October 2017. The several heads of state that had joined the International Forum on the BRI in Beijing a few weeks before the Party Congress, allowed the Chinese leader to present himself to his comrades as a symbol of a new China, a global superpower capable to shape the future of the world.

The Congress reinforced Xi Jinping's rise to power and included his ideology ("Thought on Socialism with Chinese Characteristics for a New Era") and the BRI into the Party Constitution (Constitution of the Communist Party of China, 2017). Furthermore, Wang Huning and Wang Yang, two of the five members of the BRI Small Leading Group-a special body established in 2015 by the Chinese leader to boost the implementation of his initiative-were promoted to the highest level of the Party hierarchy.

On these premises, the BRI, and Europe's role within it, might be entering a new era. During Xi Jinping's first mandate the BRI fatigued 
to move beyond its domestic rationale and mostly served as a powerful marketing tool to boost the leader's international prestige in order to expand his internal constituency in the run-up to the Party Congress.

However, in $\mathrm{Xi}$ Jinping's second mandate, due to the outcome of the Party Congress in fall, the BRI might regain momentum and inaugurate a new stage in China's relations with Europe. In order to understand the BRI's future potential impact on Europe, it is necessary to analyze its main economic components.

\section{THE BRI'S IMPACT ON EUROPE}

From the European perspective, the most relevant infrastructural projects of the BRI are railways and ports. The BRI's investments in railway and port infrastructure will certainly influence trade relations between China and Europe by lowering transportation costs and increasing trade volumes. New connections will develop trade and have an impact on each European country's trade turnover with Asia. A simulation by A. Garcia and J. Xu using a gravity model reveals that "a $10 \%$ reduction in railway, air, and maritime costs increases trade by $2 \%, 5.5 \%$, and $1.1 \%$, respectively" (Garcia, Xu, 2016). Nevertheless, the effects of new connections should also be analyzed in regard to the specific composition of trade flows.

Half of European countries' imports by railway from China are computers, printers, TVs, and monitors, while one-third of their exports to China are automotive components. The development of railways, hence, will have a greater impact on these sectors and on those countries whose export mix is particularly affected by products that have a high value/weight ratio or belong to supply chains where the "just in time" is particularly relevant. This dictates the need to stimulate the development of a new railway system, as it will allow achieving greater economies of scale and result in long-lasting improvements in logistics.

The cases of Germany and Italy, two strong European manufacturing powers representing continental and southern Europe respectively, may be taken as an example. In 2016, Germany imported $€ 1.85$ bn worth of goods from China by rail (2.6\% of total imports) and exported 
$€ 4$ bn worth of goods (5.2\% of total exports). Italy imported $€ 32.5$ mln worth of goods $(0.1 \%$ of total imports) and exported $€ 15.3 \mathrm{mln}$ worth of goods (5.2\% of total exports) by rail (Eurostat, 2017). Both are negligible percentages. In terms of the volume effect, as Germany exports more to China than Italy does, this provides Berlin with stronger potential to exploit the economies of scale and scope created by the development of new railway connections. In addition to this, if we look at the composition of trade, automotive industry accounts, respectively, for $32 \%$ of German and $12 \%$ of Italian exports to China, so railways will mostly benefit Germany's automotive sectors.

As a consequence, German logistics will be profoundly influenced. The BRI will have its main European railway hubs in Germany and Poland, and this will boost the competitive advantage of industries located nearby. The case of the automotive industry is quite representative. If today the Italian proximity to the Suez Canal provides a component producer based in Italy with an overall advantage of $4 / 5$ days over its German competitors (35/40 days versus 40/45 days), the development of railways might provide the German companies with 1 or 2 days of advantage over Italian producers. To conclude, the overall impact of the railway development might be more evident in Northern and Eastern Europe. This is confirmed by preliminary data that show that Germany, Poland, and the Czech Republic are the source of 80 percent of the total European railway trade with China (Eurostat Database).

However, railway transportations have been representing only a small part of Sino-European bilateral trade. In 2016, only $1 \%$ of total Sino-European trade volume was shipped by train (accounting for $2 \%$ of total trade turnover). This volume is less than the trade shipped by train between Germany and France together with Germany and Italy alone.

Furthermore, railway routes are a much more expensive option than sea shipping. Today, railway transportation costs between Europe and Asia are two to three times higher compared with maritime costs. Greater volumes, service lines, and logistics investments will certainly contribute to lower railway transportation costs and this will stimulate an increase in volume. Yet, this will not alter the main advantages of maritime routes. The OECD estimates that in 2050 Europe-Asia 
railway routes will be able to absorb between 0.5 and 1 million TEU out of a total of 20 million containers, a mere 2.5 to 5 percent of total shipments (OECD Final Report, 2010).

Moreover, huge investments will be needed in railways in order to reach these volumes. Track gauge in Europe and China is much smaller $(1,435 \mathrm{~mm})$ than in the former USSR region $(1,520 \mathrm{~mm})$, and that forces trains along the route to be unloaded and reloaded twice, pushing up transportation costs. In order to control costs along the China-Europe railway routes, long trains (greater than $2 \mathrm{~km}$ in length) should be used. But, most of the European train stations use platforms between 500 and 750 meters long and it will not be possible for them to host that kind of trains (AGTC, 2012).

The maritime route of the BRI then is going to be the most relevant component of Xi Jinping's initiative both in terms of volume (93\% of total trade in 2016) and value (61\% of total trade in 2016) of goods in the Sino-European trade. This will reinforce the status of the Mediterranean and Southern Europe as the terminal point of the main BRI shipping route (Eurostat, 2017).

According to the data provided by the Studi e Ricerche peril Mezzogiorno (SRM), the recent years saw a global transformation of maritime traffic. In 1995, the Transpacific route between Asia and America ruled the market, controlling 53\% of global traffic, while the EuropeFar East route, which connected the European markets to the Chinese manufacturing sites through the Suez Canal and the Mediterranean, absorbed a mere $27 \%$ of the global market. Twenty years later, in 2015, the distance between these two routes dropped in favor of the EuropeFar East route that today controls $42 \%$ of global traffic vis-à-vis the $44 \%$ controlled by the Transpacific route. At the same time (between 2001 and 2015), the volume of traffic that crossed the Suez Canal jumped by $124 \%$, with the Mediterranean controlling $10 \%$ of global trade.

This transformation, propelled by the epoch-making growth of the Chinese market, seems to have a virtuous impact on commercial, infrastructure, and logistical dynamics in the Mediterranean. In 2001, the Mediterranean ports managed to attract a mere $34 \%$ of the goods that passed through the Suez Canal. All the rest "escaped" through 
Gibraltar and was absorbed by Northern European ports such as Rotterdam and Hamburg. Today, however, $56 \%$ of the same traffic remains in the Mediterranean.

This "new centrality of the Mediterranean" is being intensified by the parallel impact of three concurrent factors:

- expansion of the Suez Canal in August 2015 that doubled the daily capacity of cargo transit;

- emerging "naval gigantism," or the strategic use by the main shipping companies of huge vessels (between 13,000 and 22,000 TEU) that can only be hosted by the Suez Canal;

- acceleration of global alliances made by shipping companies to reinforce their economies of scale, as in the case of the Ocean Alliance, consisted of the China Ocean Shipping Company (COSCO), CMA CGM from France, Evergreen from Chinese Taiwan, and OOCL from Chinese Hong Kong, which controls $35 \%$ of the Europe-Far East route trade and $40 \%$ of the Transpacific route trade.

These three concurrent phenomena (i.e. Suez enlargement, naval gigantism, and global alliances) are progressively reinforcing the competitive advantage of the Europe-Far East route, making it even more convenient than the Transpacific route for the Chinese cargo directed towards the American north-eastern coast. These processes provide the Mediterranean with an unprecedented "centrality" within both of China's most important trade segments with Europe and the U.S.

This development offers new opportunities to all Mediterranean ports that can provide Chinese shippers with faster access to the main European markets. This creates a fierce competition that is not limited to ports, but also involves global terminal operators, and multimodal logistics and transport service providers (Notteboom, 2015).

China's largest state-owned shipping company, COSCO, is investing massively in port infrastructure in the Mediterranean segment of the BRI. The most noteworthy of COSCO's investments is the Port of Piraeus, where the Chinese company spent $€ 5$ bn on the acquisition of $67 \%$ of the port ownership and the expansion of its terminals, 
becoming the first Chinese company to be the majority shareholder in an EU member's port ownership.

As a result of the Chinese investments, Piraeus experienced rapid growth shifting from $2 \%$ of total Mediterranean traffic absorbed in 2008 to $13 \%$ in 2015.

COSCO planned to increase the port's potential to $35 \%$ by 2018 , bringing it to the total capacity of more than 6 million TEU annually (The One Belt One Road Initiative: An Opportunity for Western Balkans, 2016). According to the Foundation for Economic and Industrial Research of Greece (2016), COSCO's investments in the Port of Piraeus may increase Greece's GDP by $0.8 \%$ by 2025 .

The Port of Piraeus is not simply growing in size but is also changing in nature. If China's plan to connect it to Budapest via a high-speed train system succeeds, the port will be transformed from a transshipment station into China's main gateway for Central and Eastern Europe. According to the agreement signed in November 2015 between China and Hungary, the completion of the BudapestBelgrade line, the first segment of the Piraeus-Budapest railway, will be financed by the Export-Import Bank of China with a 20-year loan that covers $85 \%$ of the total $\$ 1.8$ bn needed for the construction conducted by China Railway International Corporation.

However, this agreement raised serious concerns in the European Commission, which investigated Hungary for choosing the Chinese developer without going through a public tender process as prescribed by EU public procurement regulations. In late November 2017, Chinese developers started the construction of the project in Serbia while the Viktor Orban government in Budapest announced a procurement tender for the completion of the project in the Hungarian section.

The expansion of Piraeus as COSCO's main shipping hub will allow the port to attract and absorb greater volumes not only from other ports in the Mediterranean, but also from the ports in Northern Europe, boosting competition in this sector. With the full development of the port and its related railway network that will connect it to Budapest, the most dynamic shipping companies will likely prefer to use this area as a distribution network not only for the Balkans and Eastern 
Europe but also for North African and Western European countries. Key global players like Huawei, ZTE, and Samsung are already moving in this direction (Reply by the EU Delegation to China, 2017).

The next months might be crucial for the role of the BRI in SinoEuropean relations. Xi Jinping's centralization of power after the Congress and the insertion of the BRI in the Party Constitution will allow the Chinese leader to transform the BRI from an instrumental facelift of the previous "Going Out" policy into a fully-fledged and long-lasting restructuring of global value chains designed around China. Trump's controversial approach to the EU and Brexit, potentially growing tensions between Washington and Beijing on trade, the EU's need for infrastructural development, lack of security conflicts between China and Europe and their mutual interest in economic revitalization and security in the Mediterranean and the Middle East, are all factors that might favor Sino-European cooperation within the BRI framework.

Some interesting progress is already happening in this direction. While recent China's infrastructure investments in Europe have targeted individual countries rather than the EU as a whole, China's membership in the European Bank for Reconstruction and Development (EBRD), the EBRD's and the European Investment Fund's agreements with the Silk Road Fund show a positive change of direction in this regard (China: EBRD shareholder profile, 2016; Pyrkalo, 2016; European Investment Fund, 2017). Furthermore, the launch of the China Railway International Corporation within the Connectivity Framework should help in promoting synergy between China's BRI and the EU' Trans-European Transport Network policy and favor cooperation in areas such as infrastructure, equipment, technologies, and standards.

Anyway, until today the structural incapacity of Brussels to coordinate and centralize continental industrial and infrastructure policies coupled with the EU members' after-crisis thirst for investments, have been making the BRI impact on Europe yet another occasion for internal division and competition (as shown by the case of Belgrade-Budapest railway). 
The ambitious upgrade of the BRI in Xi Jinping's second mandate might impose an existential alternative on Europe: either deadly Balkanization of economic strategies, or a futuristic restructuring of the European mechanism that will empower the EU to actively influence the course of China's new emerging order.

\section{References}

AGTC, 2012. European Agreement on Important International Combined Transport Lines and Related Installations (AGTC). Economic Commission for Europe. Inland Transport Committee, Working Party on Intermodal Transport and Logistics, Fifty-fifth session, Geneva, November 6-7. Available at: http://www.unece.org/fileadmin/DAM/trans/doc/2012/sc2/ECE-TRANSSC22012-01-ECE-TRANS-WP24-2012-05e.pdf

China: EBRD shareholder profile, 2016. European Bank for Reconstruction and Development, January. Available at: http://www.ebrd.com/who-we-are/structure-and-management/shareholders/china.html

Constitution of the Communist Party of China, 2017. Revised and adopted at the 19th National Congress of the Communist Party of China on 24 October. Available at: http://www.china.org.cn/20171105-001.pdf

EU-China FDI Monitor, 2016. 4Q 2015. Update: Public Version, 2016. European Commission, January. Available at: http://trade.ec.europa.eu/doclib/ docs/2016/march/tradoc_154343.pdf

European Investment Fund, 2017. EIB Group cooperation with China to be strengthened with new EUR 500 million Silk Road Fund equity investment initiative. 2 June. Available at: http://www.eif.org/what_we_do/ equity/news/2017/ eib_silk_road_fund_initiative.htm?lang=-en

Eurostat, 2017. Eurostat - EXTRA EU trade since 2000 by mode of transport (HS2-HS4) [DS-043327]. Last update: 15-12-2017.

Eurostat Database. Available at: http://ec.europa.eu/eurostat/data/database

Foundation for Economic \& Industrial Research, 2016. The economic impact of the privatization of the Piraeus Port Authority: Summary. March. Available at: http://iobe.gr/docs/research/en/RES_03_08032016_PRE_EN.pdf

Garcia, A. and Xu, J., 2016. China's Belt and Road initiative: Can Europe expect trade gains? Bruegel Working Paper, No. 5. Available at: http://bruegel.org/wpcontent/uploads/2016/09/WP-05-2016.pdf 
Michael, M., 2016. Xi Jinping's focus on foreign trips in 2015: Belt and Road Initiative. The Telegraph, 13 January. Available at: http://www.telegraph.co.uk/ sponsored/china-watch/politics/12095834/Xi-Jinpings-foreign-trips-in2015-belt-and-road-initiative.html

Notteboom, T.E., 2015. Container port competition in Europe. In: C. Y. Lee and Q. Meng, eds., Handbook of Ocean Container Transport Logistics. New York and London: Spinger, pp.75-95.

OECD Final Report, 2010. Transcontinental infrastructure needs to 2030/2050, 2010. France's gateway ports and inland connections. Meeting with Meeddm officials, Paris, 7 May. Available at: https: $\mid W w w . O e c d . O r g \backslash F u t u r e s \backslash$ Infrastructureto2030\48368193.pdf

Pyrkalo, S., 2016. EBRD, Silk Road Fund agree to cooperate. European Bankfor Reconstruction and Development, 15 June. Available at: http://www.ebrd.com/ news/2016/ebrd-silk-road-fund-agree-to-cooperate.html

Reply by the EU Delegation to China, 2017. Reply by the EU Delegation to China on recent media reports related to the Belgrade-Budapest railway project. Delegation of the European Union to China, 28 February. Available at: https:// eeas.europa.eu/delegations/ china/21594/reply-eu-delegation-china-recentmedia-reports-related-belgrade-budapest-railway-project_en

Silk Road Fund joins ChemChina in industrial investment in Pirelli \& C.SpA, 2015. China Daily, 5 June. Available at: http://www.chinadaily.com.cn/business/2015-06/05/content_20923643.htm

The One Belt One Road initiative: An opportunity for Western Balkans, 2016. Intesa Sanpaolo - International Research Network, May. Available at: http:// www.group.intesasanpaolo.com/scriptIsir0/si09/contentData/view/onebelt. pdf?id=CNT-05-00000004B2BE0\&ct=application/pdf

Vision and Actions, 2015. Vision and actions on jointly building Silk Road Economic Belt and 21st-century Maritime Silk Road. National Development and Reform Commission, 28 March. Available at: http://en.ndrc.gov.cn/newsrelease/201503/t20150330_669367.html

Why is Xi's UK trip called a "super state visit", 2015. Xinhua, 20 October. Available at: http://news.xinhuanet.com/english/2015-10/20/c_134732508.htm

Wike, R., Poushter, J., Silver, L. and Bishop, C., 2017. Globally, more name U.S. than China as world's leading economic power. Pew Research Center, 13 July. Available at: http://www.pewglobal.org/2017/07/13/more-nameu- s-than-china-as-worlds-leading-economic-power/ 